\title{
Risk Assessment of Highway in the Upper Reaches of Minjiang River under the Stress of Debris Flow
}

\author{
Mingyang Li ${ }^{1}$, Shujun Tian ${ }^{1}$, Chen Huang ${ }^{1}$, Wenqia Wu${ }^{1}$, Shiwu Xin ${ }^{2}$ \\ ${ }^{1}$ School of Civil Engineering and Architecture, Southwest University of Science and Technology, Mianyang, China \\ ${ }^{2}$ Chang'an University, Xi'an, China \\ Email:1my1009366@126.com, tsj19800702@163.com
}

How to cite this paper: Li, M. Y., Tian, S. J., Huang, C., Wu, W. Q., \& Xin, S. W. (2021). Risk Assessment of Highway in the Upper Reaches of Minjiang River under the Stress of Debris Flow. Journal of Geoscience and Environment Protection, 9, 21-34. https://doi.org/10.4236/gep.2021.97002

Received: June 18, 2021

Accepted: July 13, 2021

Published: July 16, 2021

Copyright $\odot 2021$ by author(s) and Scientific Research Publishing Inc. This work is licensed under the Creative Commons Attribution International License (CC BY 4.0).

http://creativecommons.org/licenses/by/4.0/

\section{(c) (i) Open Access}

\begin{abstract}
The southwest mountainous area is a frequent debris flow disaster area in China, which poses a serious threat to the regional roads and greatly affects the normal traffic operation and the safety of residents' lives and property. The debris flow risk assessment of highway can quantify the threat degree of debris flow to the roads. In this paper, from the perspective of villages and towns, taking the upper reaches of Minjiang River as the research area, four factors including road network density, highway disaster resistance capacity, population density and highway cost are selected, and the weight is obtained by using entropy weight method, and the debris flow vulnerability evaluation results of highway are obtained by weighted calculation. Four indexes of debris flow density, shape factor, relative height difference and annual rainfall are selected to evaluate the debris flow hazard of highway by using the information method. Based on the vulnerability and hazard evaluation results, the risk of highway debris flow is evaluated, and the results are classified and discussed. The results show that: the risk of debris flow on the upper reaches of Minjiang River is relatively low, the overall spatial distribution shows a trend of high in the East and low in the west, and the overall risk of township roads in Wenchuan county is the highest; The risk of debris flow is generally high within -10 to $30 \mathrm{~km}$ from the central fault zone of Longmenshan.
\end{abstract}

\section{Keywords}

The Upper Reaches of Minjiang River, Risk Assessment, Highway, Debris Flow

\section{Introduction}

Debris flow is one of the most common and destructive disasters in China's 
mountainous areas (Deganutti \& Tecca, 2013; Paudel et al., 2020), has a great threat to the production and life of local residents and the safety of life and property, also seriously affects the stable development of social economy, and restricts the development and utilization of mountain resources (Raúl \& Susana, 2006). Highway is the main mode of transportation in mountainous areas. As a linear project, it passes through various landforms (Ferrero \& Migliazza, 2013). Moreover, highway is the main channel and artery for the external connection of mountainous towns (Tian et al., 2019), which is inevitably threatened by debris flow. Traditionally, the evaluation of highway debris flow disaster is mostly from the perspective of "line" (Tian et al., 2013b; Yin \& Zhang, 2018), and debris flow, as a geomorphic phenomenon, has geomorphic zonality, and also has the law of regional distribution difference. Therefore, it is necessary to evaluate the highway debris flow disaster from the regional perspective (Kazakova et al., 2017; Sun et al., 2021). The risk assessment of highway geological disasters can quantify the risk value of highway geological disasters in different regions, understand the extent of highway damage, carry out targeted disaster prevention and management measures, and ensure the long-term development of society and economy (Ding et al., 2020).

As for debris flow, scholars have studied the characteristics of debris flow activities (Wang et al., 2013; Sepúlveda et al., 2015; Xiong et al., 2020) to master its development law (Santi et al., 2011), which can effectively establish a debris flow evaluation model to assess the vulnerability (Sujatha, 2020) and hazard (Corominas et al., 2013; Kim et al., 2016) or risk (Budetta, 2002; Wieczorek et al., 2004; CUI et al., 2013; Ali et al., 2021), and put forward effective and reasonable control measures (Youssef et al., 2014). Through literature review, it is found that the research on highway debris flow disaster has not been evaluated from a regional perspective. As the basic carrier of social and economic development in mountainous areas, the highway is an important hub for social and economic exchanges, and the debris flow seriously affects the normal traffic of the township highway, so it is very important to evaluate the risk of debris flow on the township highway.

In this paper, 81 villages and towns in the upper reaches of Minjiang River are taken as the evaluation unit, and the vulnerability of highway under debris flow stress is evaluated from the perspectives of society, economy and highway itself; Based on 1800 Small Watersheds in the upper reaches of Minjiang River, the risk of highway in the upper reaches of Minjiang River under the stress of debris flow was evaluated by using information method; Finally, according to the vulnerability and risk assessment results of highway debris flow, the highway risk in the upper reaches of Minjiang River under the stress of debris flow is quantified, which provides scientific guidance and reference for highway planning and construction and disaster prevention and mitigation management in southwest mountainous areas. It is not only conducive to promoting regional social and economic development, but also has important scientific significance for the development of highway disaster prevention and control research and other related fields. 


\section{Overview of the Study Area}

The upper reaches of Minjiang River are the area covered by the reach above Dujiangyan of Minjiang River and its tributaries. It is the transitional zone between Qinghai Tibet Plateau and Sichuan Basin, located at $30 \mathrm{n}^{\circ} 45^{\prime}-33^{\circ} 10^{\prime}, 102$ $\mathrm{e}^{\circ} 35^{\prime}-103^{\circ}$ The study area is about $2.29 \mathrm{M} \times 104 \mathrm{~km}^{2}$, There are 81 townships including Songpan County, Heishui County, Mao County, Li County, Wenchuan County and Longchi town in Dujiangyan (Figure 1). The geological landforms in this area are complex and diverse, and the geological structure movement is frequent. The Longmenshan earthquake fault zone is included in this area. The geological disasters such as collapse, landslide and debris flow occur frequently, among which the debris flow development has the most serious impact. The highways in the upper reaches of Minjiang River are mainly distributed along the main stream of Minjiang River and its tributaries. Especially after the 2008 Wenchuan earthquake triggered the development of a large number of debris flows, the upper reaches of the Minjiang River Highway suffered serious damage. In August 2010, debris flow disasters occurred in Yingxiu Town, Xuankou Town, Yinxing Township and other towns in Wenchuan County, resulting in multiple blocking of the Wenchuan section of G213 line, resulting in 11 deaths and direct economic losses of 1.03 billion yuan; In July 2013, a debris flow broke out in Qipan gully, Weizhou Town, Wenchuan County, blocking Chengdu Wenchuan expressway; In August 2019, mud rock flow occurred in many places in Wenchuan County, and many sections of Duwen Expressway and national highway G213 were damaged, resulting in highway interruption. The disaster caused a total of 12 deaths, and the direct economic loss of the whole county reached more than 1.4 billion yuan (Figure 2). After the Wenchuan earthquake, debris flow will affect the normal operation of the highway in the upper reaches of Minjiang River for a long time, and restrict its social and economic development.

\section{Establishment of Highway Debris Flow Risk Assessment System}

In 1992, the United Nations Department of Humanitarian Affairs gave the definition of natural disaster risk: "risk is the expected loss of people's life, property and economic activities caused by a certain natural disaster in a certain region and a given period of time". The mathematical expression is: risk = vulnerability $\times$ hazard (United Nations, 1991).

\subsection{Debris Flow Vulnerability Evaluation System of Highway}

From three aspects of highway, society and economy, this paper selects highway network density, highway disaster resistance ability, population density and highway cost to establish the debris flow vulnerability of highway evaluation index system.

1) Highway network density 
M. Y. Li et al.

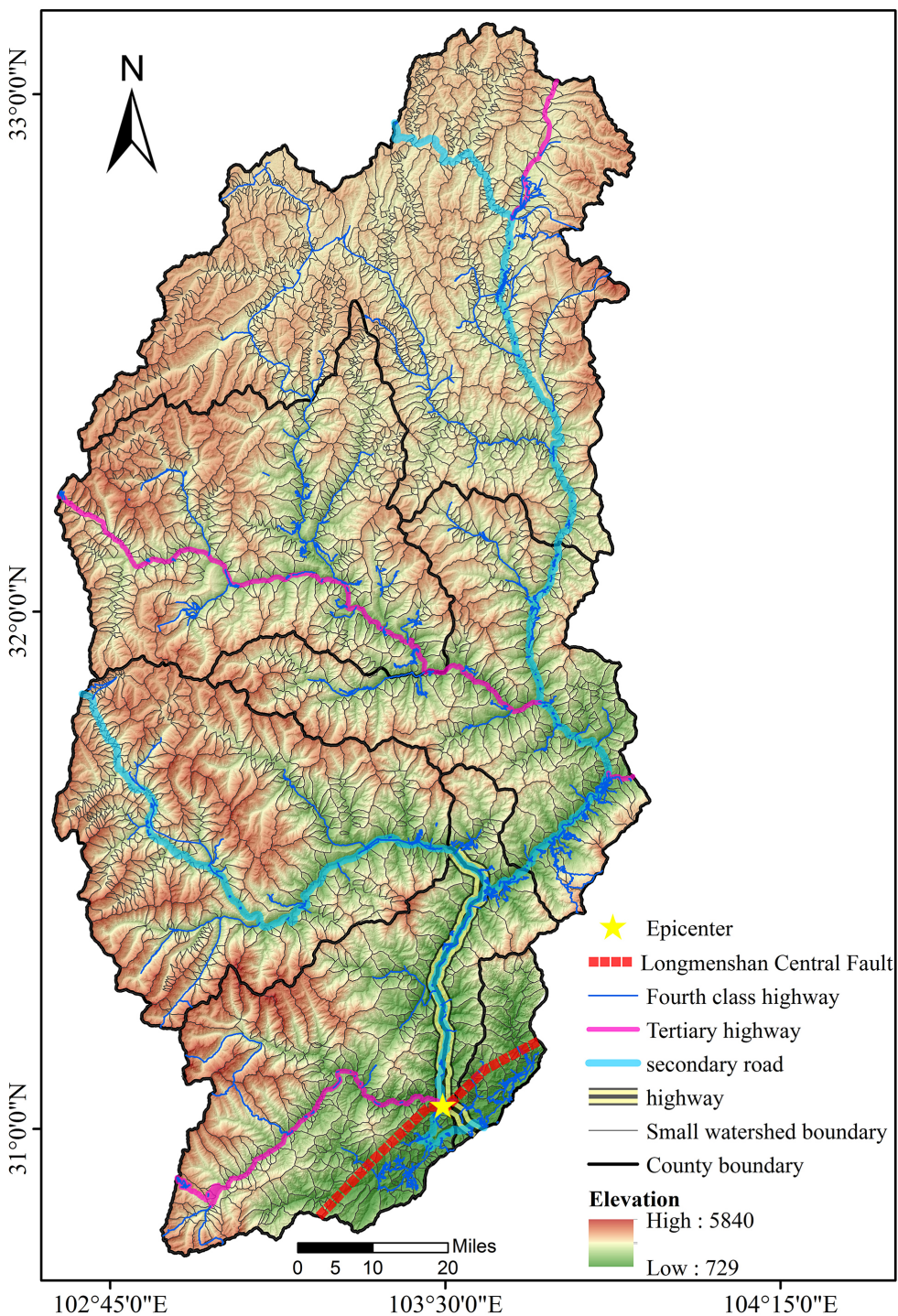

Figure 1. General situation of highway and debris flow in the upper reaches of Minjiang River.

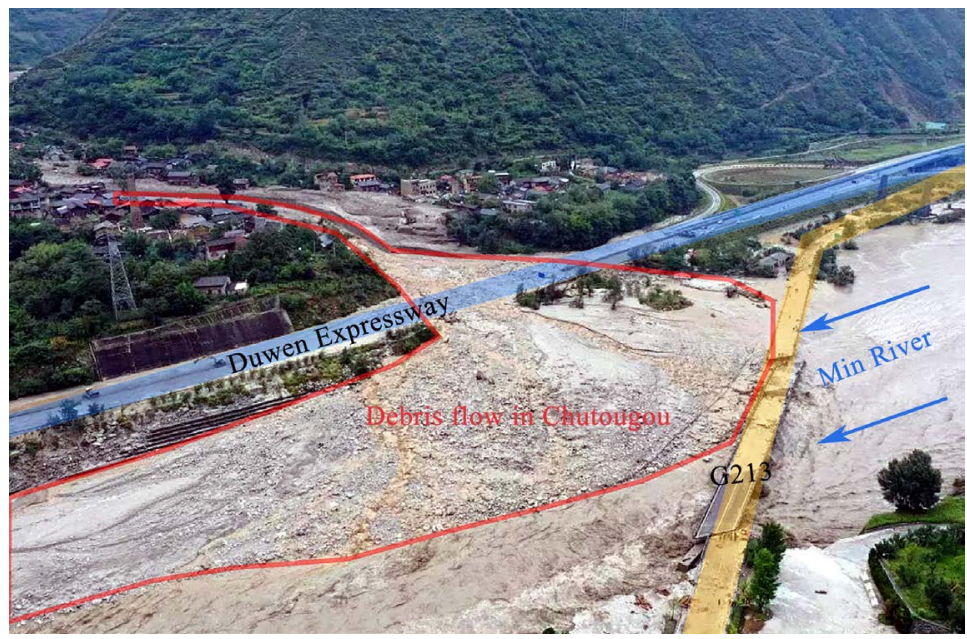

Figure 2. Destruction of highways caused by debris flow in Chutougou. 
When the debris flow disaster occurs, the higher the density of the highway network, the more detours available, and the greater the emergency rescue capacity, that is, the smaller the vulnerability of the highway (Jenelius \& Mattsson, 2015; Bíl et al., 2015; Tian et al., 2019). The calculation formula of highway network density is as follows:

$$
D=\sum_{i=1}^{4} n_{i} l_{i} / S
$$

where: $D$ is the density of regional highway network; $n$ is the conversion coefficient of each grade highway; $l$ is the length of a certain grade highway in the area; $S$ is the area of the area; $i$ is the type of highway grade existing in the area.

Because the design capacity of different grades of highways has different influence on the highway network density (Table 1), according to JTGD20-2017 highway route design specification, the conversion coefficient of highway grade is characterized by the ratio of design capacity of different grades of highways (Meraj et al., 2015; Tian et al., 2019).

2) Highway disaster resistance ability

Highway disaster resistance refers to the ability of highway to resist disasters when disasters occur in a region (Ma et al., 2013). The higher the highway grade is, the better its infrastructure is, and the stronger its ability to resist debris flow and other disasters is, that is, the lower its vulnerability is. The calculation formula of disaster resistance index of each grade highway is as follows:

$$
\eta=\sum_{i=1}^{4} T_{i} \beta_{i}
$$

where: $\eta$ is to the highway disaster resistance capacity; $T$ is the disaster resistance index of a certain grade of highway in the township; $\beta$ is the proportion of a certain grade highway in the total highway mileage in the township; The meanings of other symbols are the same as above.

3) Population density

When debris flow occurs, the greater the population density along the highway, the greater the impact of debris flow on Residents' production, life and transportation, and the greater the loss of residents' life and property (Liu et al., 2002; Armenakis \& Nirupama, 2013), that is, the higher the debris flow vulnerability of highway of Minjiang River.

4) Highway cost

The higher the cost of the highway, the greater the loss caused by debris flow disaster in the region (Jaiswal et al., 2010; Li et al., 2015) is. The upper reaches of Minjiang River are typical mountainous environment. Therefore, the average cost of highway in mountainous area is selected. Based on the experience of highway construction and statistical yearbook of China, the average cost of highway in the upper reaches of Minjiang River is calculated, including 60 million yuan $/ \mathrm{km}$ for expressway, 30 million yuan/ $\mathrm{km}$ for secondary highway, 15 million yuan/km for grade III Highway and 6 million yuan/km for class IV Highway. The calculation formula of township highway cost is: 
Table 1. Design capacity of roads in the upper reaches of Minjiang River.

\begin{tabular}{ccccc}
\hline & \multicolumn{4}{c}{ Highway grade } \\
\cline { 2 - 5 } & Expressway & $\begin{array}{c}\text { Second } \\
\text { class highway }\end{array}$ & $\begin{array}{c}\text { Third } \\
\text { class highway }\end{array}$ & $\begin{array}{c}\text { Fourth } \\
\text { class highway }\end{array}$ \\
\hline $\begin{array}{c}\text { Design capacity } \\
\text { pcu/(h.ln) }\end{array}$ & 2200 & 1100 & 600 & 400 \\
\hline
\end{tabular}

$$
E=\sum_{i=1}^{4} X_{i} l_{i} / S
$$

where: $E$ is highway cost; $X$ is the average cost per kilometer of a certain grade highway in the region; The meanings of other symbols are the same as above.

The debris flow vulnerability evaluation index of highway is normalized, and the entropy weight method is used to determine the index weight:

$$
V=\sum_{j=1}^{4} \mu_{j} W_{j}
$$

where: $V$ is the vulnerability of highway debris flow; $\mu$ is the normalized value of highway debris flow vulnerability evaluation index; $W$ is the weight of evaluation index; $j$ is the vulnerability evaluation index of highway debris flow.

\subsection{Debris Flow Hazard Evaluation System of Highway}

Highway is the main transportation mode in the upper reaches of Minjiang River, and as a kind of line project crossing various terrain and landform; it is inevitable to be threatened by debris flow, while small watershed is the basic carrier of debris flow development. Therefore, considering the influencing factors of debris flow formation, the density, shape coefficient, relative height difference and annual rainfall of debris flow are selected as evaluation indexes to establish the debris flow hazard assessment system of highway.

1) Debris flow density

The density of debris flow (piece $/ \mathrm{km}^{2}$ ) is expressed by the ratio of the amount of debris flow in the township to the area of the township. The higher the density of debris flow is, the greater the hazard it may cause to the highway, which is a direct factor to evaluate the hazard of debris flow on the highway (Liu, 2000) (Figure 3).

\section{2) Shape factor}

The shape factor represents the runoff concentration capacity in a small watershed. When the shape factor is closer to 1 , that is, the shape of a small watershed is more similar to a circle, the stronger its confluence capacity is, the easier it is to form a larger flood peak in a short time, and the greater the hazard of debris flow (Tian et al., 2013a). The calculation formula is as follows:

$$
F=\frac{4 A}{\pi L^{2}}
$$

where: $F$ is the shape factor; $A$ is the area of small watershed; $L$ is the main channel length. 


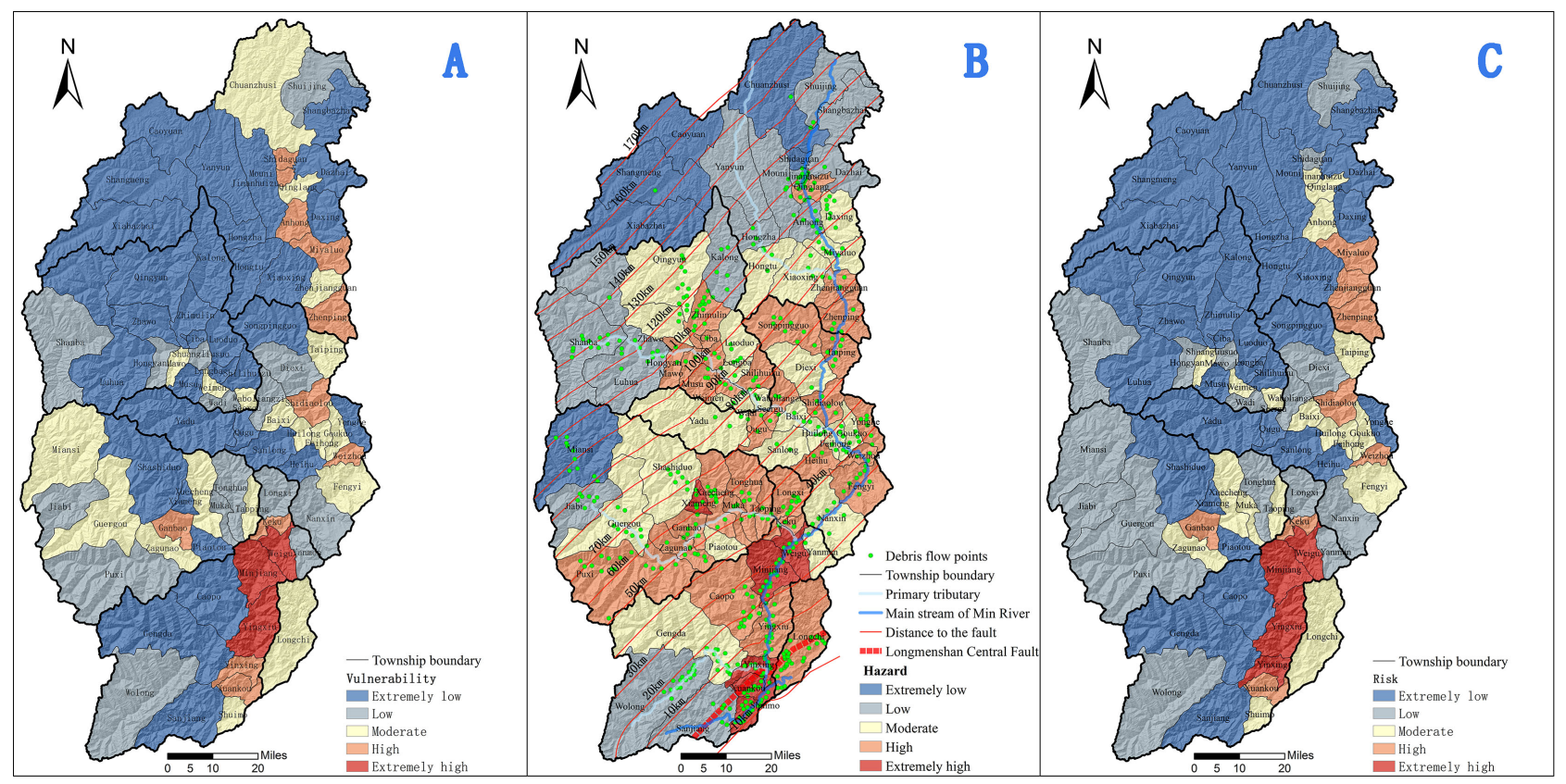

Figure 3. Debris flow vulnerability (A), hazard (B) and risk (C) classification map of highway in the upper reaches of the Minjiang River.

\section{3) Relative height difference}

As the basic carrier of debris flow, the higher the relative elevation difference, the greater the potential energy, the greater the transformed kinetic energy, the greater the speed and destructive power of debris flow, that is, the higher the hazard of debris flow (Li \& Huang, 2011; Anbazhagan \& Ramesh, 2014). Based on the DEM (digital elevation model) data of the study area, the relative elevation difference of 1800 Small Watersheds in the upper reaches of Minjiang River was calculated by using GIS platform.

4) Annual rainfall

Rainfall is an important water source condition for the initiation of debris flow in a small watershed. The greater the annual rainfall in a small watershed is, the more material will be gathered in the gully through rainfall erosion, and the greater the hazard of debris flow development (Bacchini \& Zannoni, 2003; Das et al., 2011; Winter et al., 2013). Based on the annual rainfall data of the study area, the annual rainfall of 1800 Small Watersheds in the upper reaches of Minjiang River was calculated by using GIS platform.

The information method is used to calculate the debris flow hazard of highway:

$$
H_{m}=\sum B_{m}
$$

where: $H$ is the debris flow hazard of township highways; $B$ is the information quantity of the debris flow hazard evaluation index of highway in the township; $m$ is a township in the upper reaches of Minjiang River.

\section{Analysis of Evaluation Results}

1) Calculate the mileage of various grades of roads in the upper reaches of the Minjiang River, and combine the related formulas and table data of vulnerability 
indicators to obtain the road network density, road disaster resistance capacity, and road cost of the township roads in the study area, and calculate them according to the statistical yearbook of the study area. The population density of the towns and towns in the upper reaches of the Minjiang River; the entropy weight method is used to obtain the road debris flow vulnerability evaluation index weight, and the weighted calculation is based on the highway debris flow vulnerability evaluation model.

2) Based on the debris flow hazard evaluation model of highway, the indexes are processed. Firstly, the shape factor, relative elevation difference and annual rainfall of 1800 small watersheds are obtained according to the calculation formula of hazard index, and the values are classified by natural breakpoint method based on GIS platform. Secondly, the information value of each level of highway debris flow hazard evaluation index is obtained by using the information method. Finally, 1800 small watersheds are mapped to each township, and the shape factor, relative elevation difference and annual rainfall of small watersheds are obtained by superposition calculation.

3) Based on the debris flow risk assessment model of highway and substituting relevant indexes for calculation, the highway vulnerability, hazard and risk are divided into five grades: extremely low, low, moderate, high and extremely high by using the natural breakpoint method, as shown in Figure 3 .

It can be seen that the spatial distribution of debris flow vulnerability of highway in the upper reaches of Minjiang River presents a trend of low in the West and high in the East; 48 towns are in low vulnerability level and below, accounting for $59 \%$ of the total number of towns in the study area, of which the overall vulnerability level of Heishui county highway is the lowest; The towns with moderate vulnerability level and above are located along the Duwen high speed, G213, G317 and S302; The three towns with high vulnerability level are located in Wenchuan County, respectively Weizhou Town, Miansi Town and Yinxing Town. The debris flow hazard distribution of highway in the upper reaches of Minjiang River is high in the East and low in the west, high in the South and low in the north, and the hazard level of the towns along the main stream and the first tributary of Minjiang River is generally higher; The overall hazard level of Songpan county is the lowest; The towns above the high hazard level are distributed in Heishui county and Maoxian East and south of Li County, which shows the trend along the high-grade highway; Five of the six towns with extremely high hazard level are located in Wenchuan County. The debris flow risk distribution of highway in the upper reaches of Minjiang River shows a trend of high in East and low in West; The towns with very low risk level are mainly distributed in Songpan county and Heishui County, and the overall risk level of highway in Heishui county is the lowest; The towns with medium and high risk levels of debris flow are located along the high-grade highway and are distributed uniformly; All four towns with high risk level are located in Wenchuan County, including Weizhou Town, Miansi Town, Yinxing Town and Yingxiu town. 


\section{Discussion}

Using Origin software to analyze the relationship between the data in the process of highway debris flow risk evaluation, the evaluation results are as follows.

1) It can be seen from Figure 4 that the small watershed with high hazard of debris flow is distributed in the area 20 to $100 \mathrm{~km}$ away from Wenchuan earthquake earthquake fault zone (central fault zone of Longmenshan). The number of small basins in the range of 0.5 to 0.8 indicates that the whole small watershed is more dangerous. From Figure 5, it can be seen that the smaller the overall area of towns, the smaller the small watershed, the greater the hazard of highway debris flow, indicating that the higher the hazard of small watershed in these towns, combining Figure 4 and the distribution of townships, it can be seen that the high-risk townships are close to the Wenchuan earthquake seismogenic fault zone (Longmenshan central fault zone); the overall risk degree shows an increasing trend with the increase of hazard, and the high-risk townships are concentrated in the distance The fault zone is within the range of -10 to $30 \mathrm{~km}$. The reason is that the small watershed in these towns is affected by Wenchuan earthquake, and the mountains are loose and scattered during the earthquake, which provides sufficient material sources for the formation of debris flow, which makes debris flow activity frequent; With the increase of distance, the influence of Wenchuan earthquake gradually weakened, and the hazard of debris flow is generally low. At the same time, the area is a developed area in the upper reaches of Minjiang River, with high highway grade and greater threat from debris flow. With the increase of distance, the influence of Wenchuan earthquake gradually weakened, and the debris flow hazard degree and debris flow risk degree of highway were relatively small. The prevention and control of debris flow in towns within the range of -10 to $30 \mathrm{~km}$ should be strengthened, especially in Wenchuan County. For other towns with relatively small risk of debris flow, mud rock protection projects can be built properly; meanwhile, the highway network density of towns within the range of -10 to $30 \mathrm{~km}$ is increased, and the high-grade highways along the line are maintained and strengthened.

2) The hazard degree, vulnerability and risk degree of different counties and towns are grouped and statistical, and the results are shown in Figure 6. It can be seen that the risk degree increases with the increase of vulnerability. The debris flow vulnerability, hazard and risk of in Wenchuan County are the highest, among which, the debris flow hazard and risk of in Miansi Town are the highest, and that of highway debris flow in Weizhou is the highest. Along Miansi Town, Weizhou Town, Yinxing Town and Yingxiu Town, the risk degree is generally high, and it is distributed in a belt. This belt is the section from Yingxiu to Wenchuan (Weizhou town) of Duwen expressway. Due to the strong debris flow development near the central fault zone of Longmenshan, debris flow is developed strongly. In 2010, 2013, 2019 and 2020, debris flow should be mass flow to destroy the highway, which will cause the traffic interruption of Wenchuan County. As this line is the hub and bottleneck of the external connection of the whole upper reaches of Minjiang River, the prevention and control of disasters should 
be strengthened to reduce the damage of debris flow to the highway by combining blocking and drainage; From the perspective of highway planning, the bypass and detour routes of this line should be improved, the ability of highway network to resist debris flow should be strengthened, and the degree of damage caused by debris flow to its highway network should be reduced. Meanwhile, sufficient highway rescue equipment and materials should be arranged to improve the emergency rescue capability after debris flow disaster damages the highway. The smooth of this line can be ensured by various means, Reduce its impact on social and economic development.

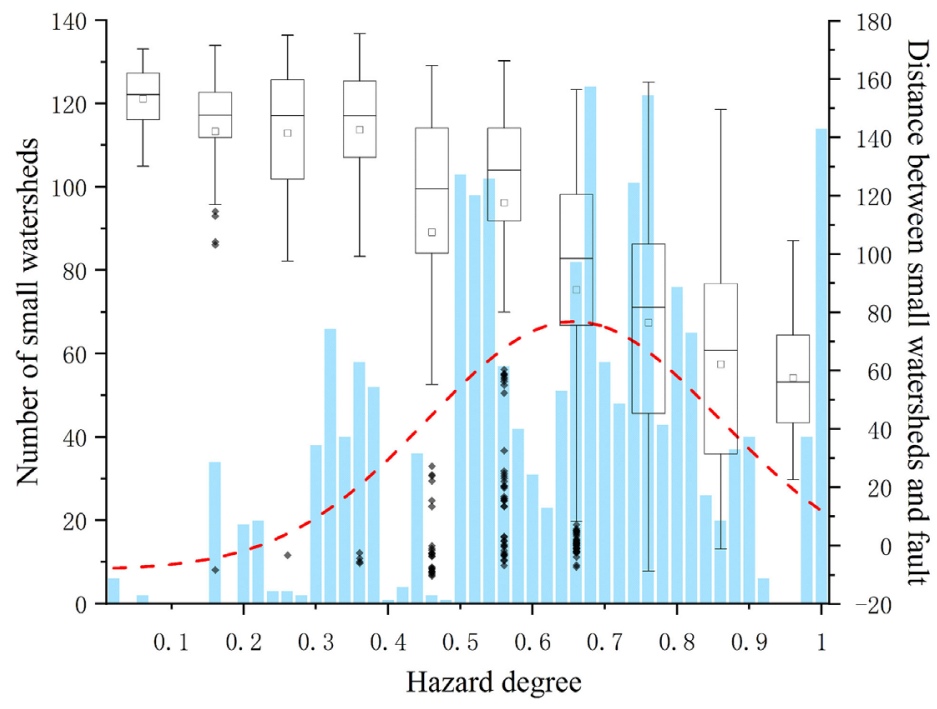

Figure 4. Distribution Diagram of the hazard of debris flow in small basin of the upper Minjiang River.

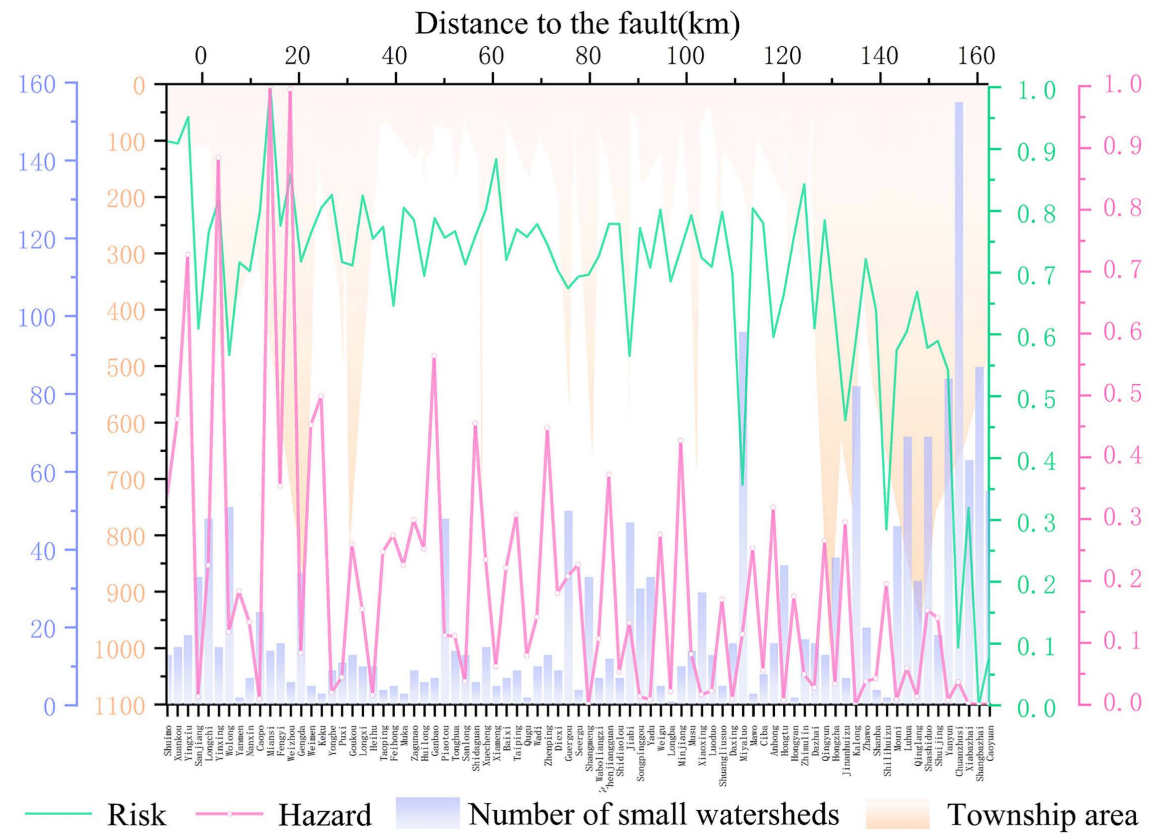

Figure 5. Diagram of the relationship between the debris flow hazard degree and the debris flow risk degree of highway. 


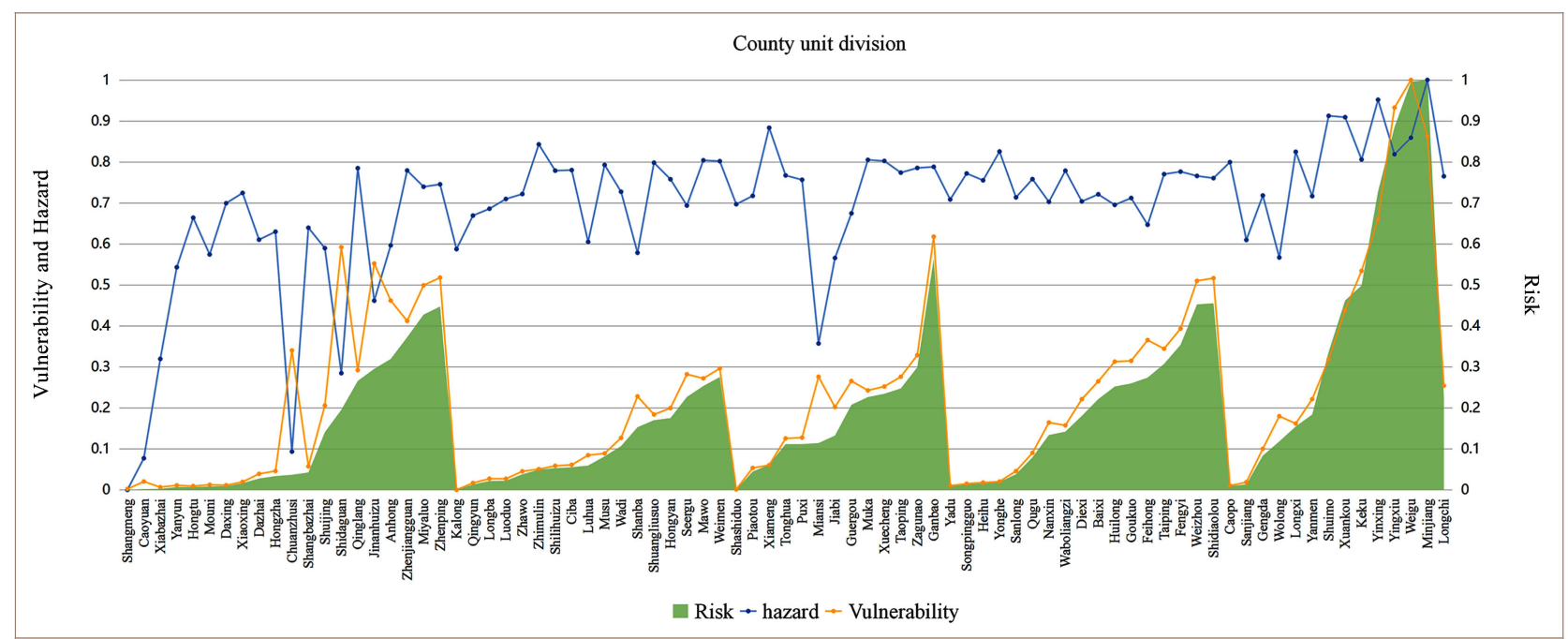

Figure 6. The relationship diagram of vulnerability, hazard and risk of county unit.

\section{Conclusion}

Based on the 1800 small watersheds and debris flow density in the upper reaches of the Minjiang River, this paper quantifies the debris flow hazard of highway, and combines the debris flow vulnerability of highway assessment results to conduct the debris flow risk of highway assessment in 81 towns in the study area. The conclusions are as follows:

1) The debris flow vulnerability of highway in the upper reaches of Minjiang River is low as a whole, and the spatial distribution shows a trend of low in the West and high in the East; The villages and towns with moderate vulnerability and above are located along the high-grade highway. The debris flow hazard of highway along the upper reaches of Minjiang River is relatively high, and the spatial distribution of debris flow is high in the East, low in the west, high in the South and low in the north; The villages and towns above high hazard level are concentrated in Heishui County, Maoxian county and Lixian County, showing a trend of distribution along the high-grade highway. The debris flow risk of highway in the upper reaches of Minjiang River is relatively low, and the overall spatial distribution shows a trend of high in the East and low in the West.

2) The villages and towns with a small number of small watersheds and relatively high risk are mainly distributed near the fault zone. The debris flow vulnerability, hazard and risk of highway in Wenchuan County are the highest in the range of -10 to $30 \mathrm{~km}$ from the fault zone. The risk of debris flow in Miansi Town, Weizhou Town, Yinxing town and Yingxiu town is generally high, and the distribution is in a belt. The villages and towns of Wenchuan County in the region were greatly affected by the Wenchuan earthquake, and the mountains were loosened and scattered in the earthquake, which provided sufficient material sources for the formation of debris flow and made the debris flow activities frequent; At the same time, Wenchuan county is an economically developed area in the upper reaches of Minjiang River. The highway grade is high as a whole, 
and it is threatened by debris flow.

3) From the perspective of disaster prevention and control, we should strengthen the prevention and control of debris flow in the range of -10 to $30 \mathrm{~km}$, especially in the villages and towns from Yingxiu to Wenchuan (Weizhou town) section of $\mathrm{Du}$ Wen expressway, and reduce the damage of debris flow to the highway through the combination of blocking and drainage; From the perspective of highway planning, the highway network density of villages and towns within -10 to $30 \mathrm{~km}$ should be increased, and sufficient highway rescue equipment and materials should be arranged to ensure the smooth highway and reduce its impact on social and economic development. Through the debris flow risk assessment of highway in the upper reaches of Minjiang River, it can provide ideas and reference for the risk assessment of highway geological disasters in southwest mountainous areas.

\section{Fund Project}

This research was supported by the Natural Science Foundation of China (Project No. 41971214 and 41877524).

\section{Conflicts of Interest}

The authors declare no conflicts of interest regarding the publication of this paper.

\section{References}

Ali, S., Haider, R., Abbas, W. et al. (2021). Empirical Assessment of Rockfall and Debris Flow Risk along the Karakoram Highway, Pakistan. Natural Hazards, 106, 2437-2460. https://doi.org/10.1007/s11069-021-04549-4

Anbazhagan, S., \& Ramesh, V. (2014). Landslide Hazard Zonation Mapping in Ghat Highway Section of Kolli Hills, India. Journal of Mountain Science, 11, 1308-1325. https://doi.org/10.1007/s11629-012-2618-9

Armenakis, C., \& Nirupama, N. (2013). Prioritization of Disaster Risk in a Community Using GIS. Natural Hazards, 66, 15-29. https://doi.org/10.1007/s11069-012-0167-8

Bacchini, M., \& Zannoni, A. (2003). Relations between Rainfall and Triggering of Debris-Flow: Case Study of Cancia (Dolomites, Northeastern Italy). Natural Hazards \& Earth System Sciences, 3, 71-79. https://doi.org/10.5194/nhess-3-71-2003

Bíl, M., Vodák, R., Kubeek, J. et al. (2015). Evaluating Highway Network Damage Caused by Natural Disasters in the Czech Republic between 1997 and 2010. Transportation Research Part A, 80, 90-103. https://doi.org/10.1016/j.tra.2015.07.006

Budetta, P. (2002). Risk Assessment from Debris Flows in Pyroclastic Deposits along a Motorway, Italy. Bulletin of Engineering Geology and the Environment, 61, 293-301. https://doi.org/10.1007/s10064-002-0161-6

Corominas, J., Ibarbia, I., Luzuriaga, S. et al. (2013). Rockfall and Debris Flow Hazard Assessment of the Coastal Road of Gipuzkoa (Northern Spain). In C. Margottini, P. Canuti, \& K. Sassa (Eds.), Landslide Science and Practice Volume 6: Risk Assessment, Management and Mitigation (pp. 223-229). Berlin: Springer. https://doi.org/10.1007/978-3-642-31319-6_31

Cui, P., Xiang, L.-Z., \& Zou, Q. (2013). Risk Assessment of Highways Affected by Debris 
Flows in Wenchuan Earthquake Area. Journal of Mountain Science, 10, 173-189. https://doi.org/10.1007/s11629-013-2575-y

Das, A. M., Kumar, N. S., \& Kanti, M. S. (2011). Landslide Hazard and Risk Analysis in India at a Regional Scale. Disaster Advances, 4, 26-39.

Deganutti, A. M., \& Tecca, P. (2013). The Case Study of Cancia (Dolomites, Italy), a Mountain Village Threatened by a Debris Flow. In C. Margottini, P. Canuti, \& K. Sassa (Eds.), Landslide Science and Practice Volume 6: Risk Assessment, Management and Mitigation (pp. 329-333). Berlin: Springer. https://doi.org/10.1007/978-3-642-31319-6_44

Ding, Y., Wang, P., Liu, X. et al. (2020). Risk Assessment of Highway Structures in Natural Disaster for the Property Insurance. Natural Hazards, 104, 2663-2685. https://doi.org/10.1007/s11069-020-04291-3

Ferrero, A. M., \& Migliazza, M. (2013). Landslide Transportation Network and Lifelines: Rockfall and Debris Flow. In C. Margottini, P. Canuti, \& K. Sassa (Eds.), Landslide Science and Practice Volume 6: Risk Assessment, Management and Mitigation (pp. 161-170). Berlin: Springer. https://doi.org/10.1007/978-3-642-31319-6_23

Jaiswal, P., Van, W., \& Jetten, V. (2010). Quantitative Assessment of Direct and Indirect Landslide Risk along Transportation Lines in Southern India. Natural Hazards and Earth System Sciences, 10, 1253-1267. https://doi.org/10.5194/nhess-10-1253-2010

Jenelius, E., \& Mattsson, L. G. (2015). Highway Network Vulnerability Analysis: Conceptualization, Implementation and Application. Computers Environment \& Urban Systems, 49, 136-147. https://doi.org/10.1016/j.compenvurbsys.2014.02.003

Kazakova, E., Lobkina, V., Gensiorovskiy, Yu., \& Zhiruev, S. (2017). Large-Scale Assessment of Avalanche and Debris Flow Hazards in the Sakhalin Region, Russian Federation. Natural Hazards, 88, 237-251. https://doi.org/10.1007/s11069-016-2431-9

Kim, H.-S., Chung, C.-K., Kim, S.-R., \& Kim, K.-S. (2016). A GIS-Based Framework for Real-Time Debris-Flow Hazard Assessment for Expressways in Korea. International Journal of Disaster Risk Science, 7, 293-311. https://doi.org/10.1007/s13753-016-0096-3

Li, J. C., Yin, C., Tian, W. P., \& Zhang, Q. L. (2015). Vulnerability Assessment of Highway Natural Disasters in China. Journal of Beijing University of Technology, 41, 1067-1072.

Li, Q., \& Huang, Y. (2011). Research on the Risk Assessment of Debris Flow in Xinjiang Tianshan Highway. Journal of Natural Disasters, 20, 154-158.

Liu, X. L. (2000). Research Progress in Regional Debris Flow Risk Assessment. Chinese Journal of Geological Hazard and Control, 13, 3-11.

Liu, X. L., Yue, Z. Q., Tham, L. G. et al. (2002). Empirical Assessment of Debris Flow Risk on a Regional Scale in Yunnan Province, Southwestern China. Environmental Management, 30, 249-264. https://doi.org/10.1007/s00267-001-2658-3

Ma, B. C., Yin, C., \& Li, J. (2013). Preliminary Study on the Evaluation and Classification of Highway Disaster-Resistant Service Capacity. Highway, 58, 138-141.

Meraj, G., Romshoo, S. A., Yousuf, A. R. et al. (2015). Assessing the Influence of Watershed Characteristics on the Flood Vulnerability of Jhelum Basin in Kashmir Himalaya. Natural Hazards, 77, 153-175. https://doi.org/10.1007/s11069-015-1605-1

Paudel, B., Fall, M., \& Daneshfar, B. (2020). GIS-Based Assessment of Debris Flow Hazards in Kulekhani Watershed, Nepal. Natural Hazards, 101, 143-172. https://doi.org/10.1007/s11069-020-03867-3

Raúl Carreo, C., \& Susana, K. C. (2006). The Alcamayo and Cedrobamba Catastrophic Debris Flow (January, March and April 2004) in Machupicchu Area-Peru. Landslides, 3, 79-83. https://doi.org/10.1007/s10346-005-0009-9 
Rybchenko, A. A., Kadetova, A. V., \& Kozireva, E. A. (2018). Relation between Basin Morphometric Features and Dynamic Characteristics of Debris Flows-A Case Study in Siberia, Russia. Journal of Mountain Science, 15, 618-630. https://doi.org/10.1007/s11629-017-4547-0

Santi, P. M., Hewitt, K., Vandine, D. F. et al. (2011). Debris-Flow Impact, Vulnerability, and Response. Natural Hazards, 56, 371-402. https://doi.org/10.1007/s11069-010-9576-8

Sepúlveda, S. A., Moreiras, S. M., Lara, M. et al. (2015). Debris Flows in the Andean Ranges of Central Chile and Argentina Triggered by 2013 Summer Storms: Characteristics and Consequences. Landslides, 12, 115-133. https://doi.org/10.1007/s10346-014-0539-0

Sujatha, E. R. (2020). A Spatial Model for the Assessment of Debris Flow Susceptibility along the Kodaikkanal-Palani Traffic Corridor. Frontiers of Earth Science, 14, 326-343. https://doi.org/10.1007/s11707-019-0775-7

Sun, J. B., Qin, S. W., Qiao, S. S., Chen, Y., Su, G., Cheng, Q. S., Zhang, Y. Q., \& Guo, X. (2021). Exploring the Impact of Introducing a Physical Model into Statistical Methods on the Evaluation of Regional Scale Debris Flow Susceptibility. Natural Hazards, 106, 881-912. https://doi.org/10.1007/s11069-020-04498-4

Tian, J., Lin, X. S., Yu, S. S. et al. (2013a). Small Watershed Division and Analysis of Watershed Characteristics along Mountain Highways. Journal of Chongqing Jiaotong University (Natural Science Edition), 32, 467-470.

Tian, S. J., Kong, J. M., \& Chen, Z. F. (2013b). Evaluation of Slope Disaster Vulnerability Based on Highway Function. Journal of Earth Sciences and Environment, 35, 119-126.

Tian, S. J., Tang, Q. S., Zhang, S. S., Han, P. F., \& Fan, X. Y. (2019). Vulnerability Assessment of Geological Disasters in the Upper Reaches of the Minjiang River Based on the Highway Network Structure. Highway, 64, 203-208.

United Nations, Department of Humanitarian Affairs (1991). Mitigating Natural Disasters: Phenomena, Effects and Options - A Manual for Policy Makers an d Planners (pp. 1-164). New York: United Nations.

Wang, L.-M., Wu, Z.-J., Wang, P., \& Chen, T. (2013). Characteristics, Causation, and Rehabilitation of Zhouqu Extraordinarily Serious Debris Flows in 2010, China. Journal of Central South University, 20, 2342-2348. https://doi.org/10.1007/s11771-013-1742-1

Wieczorek, G. F., Mossa, G. S., \& Morgan, B. A. (2004). Regional Debris-Flow Distribution and Preliminary Risk Assessment from Severe Storm Events in the Appalachian Blue Ridge Province, USA. Landslides, 1, 53-59. https://doi.org/10.1007/s10346-003-0003-Z

Winter, M. G., Harrison, M., Macgregor, F. et al. (2013). Landslide Hazard and Risk Assessment on the Scottish Highway Network. Proceedings of the Institution of Civil Engineers Geotechnical Engineering, 166, 522-539. https://doi.org/10.1680/geng.12.00063

Xiong, J., Tang, C., Chen, M., Zhang, X. Z., Shi, Q. Y., \& Gong, L. F. (2020). Activity Characteristics and Enlightenment of the Debris Flow Triggered by the Rainstorm on 20 August 2019 in Wenchuan County, China. Bulletin of Engineering Geology and the Environment, 80, 873-888. https://doi.org/10.1007/s10064-020-01981-x

Yin, C., \& Zhang, J. L. (2018). Hazard Regionalization of Debris-Flow Disasters along Highways in China. Natural Hazards, 91, 129-147.

https://doi.org/10.1007/s11069-018-3229-8

Youssef, A. M., Pradhan, B., \& Maerz, N. H. (2014). Debris Flow Impact Assessment Caused by 14 April 2012 Rainfall along the Al-Hada Highway, Kingdom of Saudi Arabia Using High-Resolution Satellite Imagery. Arabian Journal of Geosciences, 7, 2591-2601. https://doi.org/10.1007/s12517-013-0935-0 